\title{
Seasonal Influence and Heavy Metal Analysis in Marine Shrimp (Penaeus spp.) Sold in Trinidad, West Indies
}

\author{
Sophia Balfour (Corresponding author) \\ Department of Food Production, Faculty of Science and Agriculture \\ University of the West Indies, St. Augustine \\ Republic of Trinidad and Tobago, West Indies
}

Tel: 1-868-662- 2002 Ext. 83989 E-mail: sophia_balfour@yahoo.com

\author{
Neela Badrie \\ Department of Food Production, Faculty of Science and Agriculture \\ University of the West Indies, St. Augustine \\ Republic of Trinidad and Tobago, West Indies \\ E-mail: nbadrie@yahoo.com \\ Ivan Chang Yen \\ Department of Chemistry, Faculty of Science and Agriculture \\ University of the West Indies, St. Augustine \\ Republic of Trinidad and Tobago, West Indies \\ E-mail: ichangyen@sta.uwi.tt \\ Luctchminarine Chatergoon \\ Department of Chemistry, Faculty of Science and Agriculture \\ University of the West Indies, St. Augustine \\ Republic of Trinidad and Tobago, West Indies
}

Received: December 2, 2011

Accepted: December 16, $2011 \quad$ Published: February 1, 2012

doi:10.5539/jfr.v1n1p193

URL: http://dx.doi.org/10.5539/jfr.v1n1p193

\begin{abstract}
Shrimp is a popular seafood in Trinidad and Tobago which is mainly caught in the coastal environs and sold mostly for domestic consumption. The objectives of the research were to determine if chemical contaminants copper, zinc, cadmium, chromium, nickel and mercury in the marine shrimp (Penaeus spp.) met international and local food safety standards and; to investigate any location by season interactions. Determination of all heavy metals was by flame atomic absorption spectroscopy except for mercury. Validation of methods was done using Certified Reference Materials namely dogfish liver and fish protein. The heavy metal findings in the marine shrimp were well below the United States Food and Drug Administration, Canada's Food Inspection Agency and, Trinidad and Tobago's admissible limits for human consumption. Significant differences were observed only for copper by location and season interaction and; zinc by location and season respectively.
\end{abstract}

Keywords: Heavy metal, International limit, Marine shrimp, Food safety

\section{Introduction}

Crustaceans and seafoods can be potential sources of toxic metals (Carbonell et al., 1998). While information is known worldwide on the implications of mercury, the general consensus from a regional awareness workshop on 
mercury pollution held in Port of Spain, Trinidad from 18-21 January 2005 found that there were gaps in the data for the Caribbean islands in relation to mercury levels found in air, land, soil, fish and shellfish (UNEP, 2005).

It is also noticeably evident from two studies in Trinidad that land species crustaceans found near coastal villages and mollusks exceeded heavy metal permissible limits for human consumption (Singh, 1988 and and Rojas de Astudillo, 2002). The zinc ( $\mathrm{Zn})$ and copper $(\mathrm{Cu})$ levels in two species of land crab (Cardisoma guanhumi and Ucides cordatus) collected at Guayamare, Mayaro and Cacandee during July 1985, 1986 and 1988 respectively were above the permissible limits for human consumption (Singh, 1988). The $\mathrm{Zn}$ levels in C. guanhumi crab ranged from $\left(62.94\right.$ - 85.78) $\mu \mathrm{g} \mathrm{g}^{-1}$ wet weight (wt.) and in $U$. cordatus $(64.82-67.16) \mu \mathrm{g} \mathrm{g}^{-1}$ wet wt., both exceeding Zn's local permissible limit of $50 \mu \mathrm{g} \mathrm{g}^{-1}$ wet wt. Similarly, the Cu level in C. guanhumi ranged from 22.84 to $26.78 \mu \mathrm{g} \mathrm{g}^{-1}$ wet wt., exceeding Cu's maximum permissible limit (MPL) of $20 \mu \mathrm{g} \mathrm{g}^{-1}$ wet wt. In the second study Rojas de Astudillo (2002) reported that $\mathrm{Zn}$ and Cu levels in oysters (Crassostrea spp.) from Gulf of Paria sampled in November 1999 also exceeded local MPL ( $\mathrm{Cu}=20 \mu \mathrm{g} \mathrm{g}^{-1}$ wet wt.; $\mathrm{Zn}=50 \mu \mathrm{g} \mathrm{g}^{-1}$ wet wt.) for human consumption. Similarly, Zn levels in the oysters collected at Chacachacare, Chaguaramas, Caroni, La Brea and Cedros ranged from 138.47 to $540.13 \mu \mathrm{g} \mathrm{g}^{-1}$, while the oysters sampled at Chaguaramas, La Brea and Cedros had $\mathrm{Cu}$ in the range 28.13 to $52.10 \mu \mathrm{g} \mathrm{g}^{-1}$ wet wt., many in excess of local MPL. Additionally, mussels (Perna viridis) sampled in November 1999 from the Caroni Swamp showed high levels of $\mathrm{Zn}$ at $89.23 \mu \mathrm{g} \mathrm{g}^{-1} \mathrm{wet}$ wt., in excess of the MPL.

Several countries have developed maximum acceptable concentrations for commercialization and consumption of crustacean and seafood (Carbonell et al., 1998) such as the United States, Canada and also Trinidad and Tobago, a developing country. The safety of consuming shrimp in Trinidad and Tobago is unknown. There exist no data in the literature to provide evidence for the levels of the heavy metal in Trinidad and Tobago's shrimp as well as for seasonal variations. The objectives of the study were to determine: (1) if $\mathrm{Cu}, \mathrm{Zn}$, cadmium (Cd), chromium (Cr), nickel (Ni) and mercury (Hg) were present in Trinidad's marine shrimp (Penaeus spp.), at levels which met international and local food safety standards for human consumption as summarized in Table 1, and for which relevant action may be necessary and; (2) to evaluate any location (geographical) by season interactions as well as location (geographical) and seasonal variations respectively of heavy metals $\mathrm{Cu}, \mathrm{Zn}, \mathrm{Cd}$, $\mathrm{Cr}, \mathrm{Ni}$ and $\mathrm{Hg}$ in Trinidad's marine shrimp.

\section{Materials and Methods}

\subsection{Source of shrimp, sampling protocol and collection}

Shrimp (Penaeus spp.) were purchased at four wholesale and retail fish depots along the western coastline of Trinidad at Orange Valley, Otaheiti and Sealots, Port of Spain and Claxton Bay, as well as from three road side vendors in the Tunapuna region for the period January to December 2009.

Shrimp samples $8.5-11.5 \mathrm{~cm}$ in length were purchased seasonally, four times per year from January to February, March to April, July to August and September to October in each of the five (5) selected areas from three vendors respectively on site. The total number of samples examined for this research was sixty (60): thirty (30) samples (or 2 batches each of 15 shrimp samples) in the dry season from January to May 2009 and another thirty (30) samples (or 2 batches each of 15 shrimp samples) in the rainy season from June to December 2009.

Two pounds $(800 \mathrm{~g})$ of shrimp samples obtained from each vendor were placed into sterile bags and transported to the Food Production - Microbiology laboratory at The University of the West Indies within 2 hours of purchase in an ice cooler to maintain a temperature of approximately $4{ }^{\circ} \mathrm{C}$; and then frozen at $-20^{\circ} \mathrm{C}$ until it was time to analyse for $\mathrm{Cu}, \mathrm{Zn}, \mathrm{Cd}, \mathrm{Ni}, \mathrm{Cr}$ and $\mathrm{Hg}$.

\subsection{Preparation of shrimps for heavy metal analysis}

Approximately one pound (about 400 grams) of each sampled shrimp was de-headed, de-shelled and de-veined. The shrimp tissues were then rinsed with distilled water and well drained. The shrimp were then macerated at high speed for 2 minutes using a Waring Blender (Model 31BL92, Connecticut, U.S.A). The macerated shrimp tissues were then frozen in polythene bags at $-20^{\circ} \mathrm{C}$ and heavy metal analyses were conducted within one year of purchase.

All glassware used for heavy metal and mercury analyses were washed with detergent, rinsed in distilled water, pre-soaked in $5 \%$ nitric acid for $24 \mathrm{~h}$, rinsed with de-ionised water and allowed to air-dry before use.

\subsection{Determination of $\mathrm{Cu}, \mathrm{Zn}, \mathrm{Cd}, \mathrm{Cr}$ and $\mathrm{Ni}$ in shrimps (Penaeus spp.)}

A slightly modified version of the method used by Rojas de Astudillo (2002) was carried out in this investigation. Triplicate $3 \mathrm{~g}$ aliquots of shrimp tissue macerates were weighted into boiling tubes. Concentrated analytical grade 
nitric acid $(10 \mathrm{~mL})$ was added to directly to each sample and vortexed to ensure that all the macerated shrimp tissues were fully submerged in the acid. The samples were covered with glass plates in the fume hood and allowed to predigest overnight at room temperature. Reagent blanks were processed simultaneously in triplicate. The samples were refluxed on a heating block at $130-135^{\circ} \mathrm{C}$ for 6 hours. After cooling for 20 minutes, $5 \mathrm{~mL}$ deionised water was added to dilute each sample which was then filtered into a $25 \mathrm{~mL}$ volumetric flask, using Whatman 542 filters, and made up volume with deionised water rinses of the residues. $\mathrm{Cu}, \mathrm{Zn}, \mathrm{Cd}, \mathrm{Cr}$ and $\mathrm{Ni}$ in the samples were determined by flame atomic absorption spectroscopy (FAAS) using a Varian Model SpectraAA-880 (Australia). A deuterium background correction was used for all metals except chromium. In-date commercial metal calibration standards (BDH, Poole, U.K.) were used to prepare fresh multi-element calibration standards each time that the samples were analysed.

Optimisation of the method was conducted using of $3 \mathrm{~g}$ duplicates of macerated shrimp tissue being pre-digested overnight in $10 \mathrm{~mL}$ volume of nitric acid digesting at130-135 oC, since previous studies done by Rojas de Astudillo (2002) showed that the $10 \mathrm{~mL}$ volume of nitric acid had provided optimal recoveries for the metals in shellfish. Optimization of the heavy metal method consisted of varying the reflux time at 4, 5, 6, 7 and 8 hours for obtaining the highest recoveries for $\mathrm{Cu}, \mathrm{Zn}$ and $\mathrm{Cd}$ in the shrimp samples.

$\mathrm{Cu}$ and $\mathrm{Zn}$ were chosen for optimizing the method, as shellfish tend to have high levels of $\mathrm{Cu}$ and $\mathrm{Zn}$, based on reports in published literature (Van den Broek, 1979; Singh, 1988; Guns et al., 1999; Rojas de Astudillo, 2002 \& Liang et al., 2004).

\subsection{Evaluation of plastic storage bags for possible heavy metal contamination}

Since sealed polyethylene bags were used to store the macerated shrimp samples for extended periods before heavy metal analyses were conducted, it was necessary to determine whether these bags were possible sources of contamination of the samples.

Three bags from each box of bags were randomly sampled. Into each was measured $100 \mathrm{~mL}$ of $0.1 \mathrm{M}$ nitric acid, the bags were closed and left to stand at room temperature for 1 hour. The leaching solutions from the sealed bags were analyzed by FAAS, using the nitric acid solution as a blank. The metal levels in the sealed storage bags were negligible (Cd and $\mathrm{Cr}$ : $0.00 \mu \mathrm{g} \mathrm{mL} L^{-1}$; Ni: $0.07 \mu \mathrm{g} \mathrm{mL}^{-1}$; $\mathrm{Cu} 0.01 \mu \mathrm{g} \mathrm{mL} \mathrm{L}^{-1}$ and $\mathrm{Zn}: 0.02 \mu \mathrm{g} \mathrm{mL}^{-1}$ ). The surface area of each the Ziploc bag was approximately $250 \mathrm{~cm}^{2}$.

\subsection{Determination of mercury in shrimp samples (Penaeus spp.)}

A slightly modified version of the method outlined by Rojas de Astudillo (2002) was used in this investigation. Three replicates of $3 \mathrm{~g}$ aliquots of shrimp tissue macerates were weighted into boiling tubes. Then, $10 \mathrm{~mL}$ concentrated analytical grade nitric acid was added to each macerate, and left to pre-digest overnight hours at room temperature in a fume hood, while covered with glass plates to avoid aerial contamination.

The boiling tubes were then placed on a heating block at $130-135^{\circ} \mathrm{C}$ for 3 hours. Concentrated sulphuric acid $(2.5 \mathrm{~mL})$ and concentrated hydrochloric acid $(1.0 \mathrm{~mL})$ were then added slowly to each sample, which were then allowed to reflux for 3 more hours. After cooling for 20 minutes, potassium manganate (VII) solution $(5 \% \mathrm{~m} / \mathrm{V})$ was added drop-wise to each sample until a first permanent pink coloration was observed. Hydroxlamine solution $(10 \% \mathrm{~m} / \mathrm{V})$ was immediately added to destroy the excess potassium manganate (VII). The digest was diluted with $5 \mathrm{~mL}$ deionised water, then filtered into $25 \mathrm{~mL}$ volumetric flasks, through Whatman 542 filters, and made up volume with deionised water rinses of the residues. Triplicate reagent blanks were processed simultaneously.

Hg in shrimp was determined by cold vapour atomic absorption on the Varian Model SpectraAA-880 (Australia). In-date commercial metal calibration standards (BDH, Poole, U.K.) were used to prepare fresh calibration standards each time that the samples were analysed.

\subsection{Validation of methods for $\mathrm{Cu}, \mathrm{Zn}, \mathrm{Cd}, \mathrm{Cr}$, Ni and $\mathrm{Hg}$}

The methods were validated using Certified Reference Materials (CRM) namely dogfish liver (DOLT-2) and (DOLT-4) respectively and fish muscle tissues (DORM-3) from the National Research Council of Canada with recoveries that were consistent and ranged from (91.83 to 111.89\%), with the exception of DORM-3and DOLT-4 for nickel, for which percent recoveries were slightly higher (116.95-117.33\%) as shown in Table 2. Three replicates of each CRM were subsequently analyzed with each batch of shrimp samples to monitor and control the quality of analyses.

\subsection{Statistical analyses}

Statistical analyses were carried out using Statistical Package for Social Sciences (SPSS) version 17 software. One-way Analysis of Variance (ANOVA) was used to determine significant variations in the reflux time for the 
absorbencies of $\mathrm{Cu}, \mathrm{Zn}$ and $\mathrm{Cd}$ at a $5 \%$ level of significance. Case summaries provided mean recoveries and standard errors for the CRM. Additionally, Univariate Analysis of Variance was used to determine significant differences in the interaction of location by seasons as well as significant variations of season and location respectively for each of the metal investigated in this research.

\section{Results}

\subsection{Optimization of reflux time for $\mathrm{Cu}, \mathrm{Zn}$ and $\mathrm{Cd}$}

One-way ANOVA showed that the absorbencies of $\mathrm{Cu}(\mathrm{P}=0.43), \mathrm{Zn}(\mathrm{P}=0.36)$ and $\mathrm{Cd}(\mathrm{P}=0.17)$ did not vary significantly, in relation to the reflux times of 4, 5, 6, 7 and 8 hours respectively.

\subsection{Heavy metal findings in shrimp sampled in Trinidad in 2009}

3.2.1 Heavy metal findings in shrimp from Trinidad in relation to the international and local permitted levels for human consumption of foods

The shrimp sampled in Trinidad in 2009 had metal levels well below admissible limits for human consumption according to international and local standards (US FDA, 1993; T\&T Food and Drug Regulation, 2007 \& CFIA, 2009) as shown in Table 1. Additionally, the shrimp sampled from Claxton Bay in 2009 had Ni concentration below its limit of quantitation (LOQ) (Table 1).

3.2.2 Effect of location, season and location*season interaction of the shrimp sampled in Trinidad in 2009

Only $\mathrm{Cu}$ showed significant effects on the location by season interaction $(\mathrm{P}=0.03)$ as shown in Table 3 , with the dry season displaying higher trends of $\mathrm{Cu}$ concentrations in the shrimp samples purchased from Orange Valley followed by Otaheiti, Port of Spain, Tunapuna and Claxton Bay relative to the wet season.

Similarly, only $\mathrm{Zn}$ showed significant location $(\mathrm{P}=0.00)$ and seasonal $(\mathrm{P}=0.02)$ differences respectively. The Zn concentrations were highest in shrimp sampled at Tunapuna followed by Otaheiti, Port of Spain, Orange Valley and Claxton Bay respectively (Table 3). Additionally, the dry season showed an overall higher level of Zn in the shrimp samples relative to the wet season (Table 3).

$\mathrm{Cd}, \mathrm{Cr}, \mathrm{Ni}$ and $\mathrm{Hg}$ concentrations in the shrimp sampled in Trinidad in 2009 did not vary significantly $(\mathrm{P}>0.05)$ by location, season or location by season interaction.

\section{Discussion of Heavy Metal in Shrimp}

A sample extraction reflux time of 6 hours was used for all shrimp samples in this project, to ensure the complete decomposition of all the organic $\mathrm{Cu}, \mathrm{Zn}, \mathrm{Cd}, \mathrm{Cr}, \mathrm{Ni}$ and $\mathrm{Hg}$ into their respective inorganic forms.

The CRM namely, DOLT-4, DORM-3 and DOLT-2 validated the methods for the metals of interest to this project as shown in Table 2, with recoveries ranging from $(\mathrm{Cu}: 107.29-111.89 \%$; $\mathrm{Zn}$ : $98.28-102.65 \%$; Cd: 95.53 - 95.77\%; Cr: $91.83-96.70 \%$ and $\mathrm{Hg}: 86.67-98.60 \%$ ). This showed the method to be accurate and precise for the determination of the selected heavy metals in shrimp.

In addition, the $\mathrm{CRM}$ recoveries for the metals $\mathrm{Cu}, \mathrm{Zn}, \mathrm{Cd}, \mathrm{Cr}$ and $\mathrm{Hg}$ in this research agreed well with those found in the literature (Tu et al., 2008; Maanan, 2008 \& Cui et al., 2011). However the nickel recoveries in DORM-3 and DOLT-4 were slightly higher and ranged from (116.95 -117.33\%) which could have been attributed to possible matrix interferences (Sundberg, 1973). Nevertheless, the results of analysis were not adjusted for these recoveries for nickel.

The metal concentrations of the Penaeus shrimp species sampled in 2009 in Trinidad were well below the maximum admissible limits for human consumption according to international and local standards (US FDA 1993; CFIA 2011; and T\&T Food and Drug Regulation 2007) as shown in Table 1, which suggested that they were safe to consume; although the Gulf of Paria's coastline is considered to be heavily polluted given that it is one of the most industralised areas in the region (Dhoray \& Teelucksingh, 2007).

The metal levels found in the local Penaeid shrimp may be attributed to their short lifespan of approximately 1 to 2 years, as well as the constant movement of the shrimp during their life cycle (Kuruvilla, 2001), thus minimizing the shrimp's ability to accumulate the metals in their muscle tissue.

$\mathrm{Cd}, \mathrm{Cr}, \mathrm{Cu}, \mathrm{Zn}$ and $\mathrm{Hg}$ findings in the local shrimp (Penaeus spp.) were lower than those reported in various shrimp species from India, China, Egypt and Turkey (Guhathakurta \& Kaviraj, 2000; Soliman, 2006; Y1lmaz \& Yilmaz, 2007; Tag El-Din et al., 2009 \& Wu \& Yang, 2011), some of which exceeded the maximum admissible limits for human consumption when compared to international and local standards (US FDA, 1993; T\&T Food and Drug Regulation, 2007 \& CFIA, 2011). 
Location by season interaction varied significantly $(\mathrm{P}=0.03)$ for $\mathrm{Cu}$ concentrations in the shrimp samples with Orange Valley having the highest concentration of $3.82 \mu \mathrm{g} \mathrm{g}{ }^{-1}$ wet wt. in the dry season, followed by Otaheiti, Port of Spain, Tunapuna and Claxton Bay at 3.39, 3.28, 2.86 and $1.86 \mu \mathrm{g} \mathrm{g}^{-1}$ wet wt. versus 2.38, 1.99, 2.19, 1.66 and $1.95 \mu \mathrm{g} \mathrm{g}^{-1}$ in the wet season (Table 3). This may have resulted from the run-offs of Cu-based agricultural pesticides mostly in the dry season when crops and rice are commonly cultivated in Trinidad. These run-offs travel through streams and rivers and, ultimately into the Gulf of Paria where shrimp are short-lived, harvested and then brought to vending sites for purchase. Additionally, high $\mathrm{Cu}$ concentration in the shrimp may also be associated to the essential role of the metal in crustaceans for the metabolic functioning of proteins such as haemocyanin (White \& Rainbow, 1982).

The $\mathrm{Zn}$ concentration in the shrimp showed a significant seasonal difference $(\mathrm{P}=0.02)$ with the dry season having higher concentration of $10.15 \mu \mathrm{g} \mathrm{g}^{-1}$ wet wt. versus $9.71 \mu \mathrm{g} \mathrm{g}^{-1}$ wet wt. in the wet season (Table 3), which may be attributed to the coastal habitats being affected by anthropogenic metal contamination and possibly widespread faecal pollution (Nunez-Nogueira and Rainbow, 2005; Bachoon et al., 2010).

The significantly higher concentrations of $\mathrm{Cu}$ and $\mathrm{Zn}$ from Trinidad's shrimp in dry season were consistent with the previous study done by Rojas de Astudillo (2002), except $\mathrm{Cu}$ and $\mathrm{Zn}$ concentrations in that study were found to be above permissible limits for human consumption in other types of shellfish, namely, oysters and mussels from Trinidad and Venezuela.

Also, the shrimp sampled at Tunapuna had the highest $\mathrm{Zn}$ concentration of $10.61 \mu \mathrm{g} \mathrm{g}^{-1}$ wet wt., followed by Otaheiti, Port of Spain, Orange Valley and Claxton Bay at 10.43, 10.05, 10.02 and $8.99 \mu \mathrm{g} \mathrm{g}^{-1}$ wet wt. respectively which suggested that continuous care must be taken to monitor the metal levels in marine shrimp especially if they exceed international and local permissible limits for human consumption.

The metals levels in the Ziploc storage bags were negligible, which suggested that these storage bags were not responsible for any heavy metal contamination of the sampled shrimp.

\section{Conclusion}

The marine shrimp (Penaeus spp.) in Trinidad were safe to consume since the metal ( $\mathrm{Cu}, \mathrm{Zn}, \mathrm{Cd}, \mathrm{Cr}, \mathrm{Ni}$ and $\mathrm{Hg}$ ) concentrations were well below local and international admissible limits for human consumption. Some vending sites (locations) had higher levels of metal contamination mainly in the dry season which may have been due to anthropogenic metal contamination along the coastline or further in-land.

\section{Acknowledgements}

The authors thank Dr. G. Legall for his statistical guidance and also the late Dr. A. Donawa for his vital comments, suggestions and keen interest in the research project. The research was financed by Department of Food Production and The University of the West Indies Research and Publication Fund, St. Augustine Campus, Republic of Trinidad and Tobago, West Indies.

\section{References}

Bachoon, D. S., Markand, S., Otero, E. Garvin Perry, G.., \& Ramsubaugh, A. (2010). Assessment of non-point sources of fecal pollution in coastal waters of Puerto Rico and Trinidad. Marine Pollution Bulletin, 60(7), 1117-1121. http://dx.doi.org/10.1016/j.marpolbul.2010.04.020

Canadian Food Inspection Agency (CFIA). (2011). Fish products standards and methods manual. Appendix 3: Amend. Number 11 dated 2011, July 20. Canadian guidelines for chemical contaminants and toxins in fish and fish products.

Carbonell, G., Ramos, C., \& Tarazona, J. V. (1998). Heavy metals in shrimp culture areas from the Gulf of Fonseca, Central America. II. Cultured Shrimps. Bulletin of Environmental Contamination and Toxicology Bull., 60(2), 260-265.

Cui, B., Zhang, Q., Zhang, K., Liu, X., \& Zhang H. (2011). Analyzing trophic transfer of heavy metals for food webs in the newly-formed wetlands of the Yellow River Delta, China. Environmental Pollution, 159(5), 1297-1306. http://dx.doi.org/10.1016/j.envpol.2011.01.024

Dhoray, S., \& Teelucksingh, S. S. (2007). The implications of ecosystem dynamics for fisheries management: A case study of selected fisheries in the Gulf of Paria, Trinidad. Journal of Environmental Management, 85(2), 415-428. http://dx.doi.org/10.1016/j.jenvman.2006.10.019 
Guhathakurta, H., \& Kaviraj, A. (2000). Heavy metal concentration in water, sediment, shrimp (Penaeus monodon) and mullet (Liza parsia) in some brackish water ponds of Sunderban, India. Marine Pollution Bulletin, 40(11), 914-920, http://dx.doi.org/10.1016/S0025-326X(00)00028-X

Guns, M., P. V. Hoeyweghen, W. Vyncke \& H. Hillewaert. (1999). Trace metals in selected benthic invertebrates from Belgian Coastal Waters (1981-1996). Marine Pollution Bulletin, 38(12), 1184-1193. http://dx.doi.org/10.1016/S0025-326X(99)00156-3

Kuruvilla, S. (2001). Impact of shrimp fisheries in Trinidad and Tobago. Paper presented at Regional Workshop held in Costa Rica; 14-14 January, 2000. In Tropical shrimp fisheries and their impact on living resources, United Nations FAO Fisheries Circular. No. 974, 308-329, Rome: FAO.

Liang, L. N., He, B., Jiang, G. B., Chen, D. Y., \& Yao, Z. W. (2004). Evaluation of mollusks as biomonitors to investigate heavy metal contaminations along the Chinese Bohai Sea. Science of the Total Environment, 324(1-3), 105-113. http://dx.doi.org/10.1016/j.scitotenv.2003.10.021

Maanan, M. (2008). Heavy metal concentrations in marine molluscs from the Moroccan coastal region. Environmental Pollution, 153 (1), 176 - 183. http://dx.doi.org/10.1016/j.envpol.2007.07.024

Nunez-Nogueira, G., \& Rainbow, P. S. (2005). Kinetics of zinc uptake from solution, accumulation and excretion by the decapod crustacean Penaeus indicus. Marine Biology, 147, 93-103. http://dx.doi.org/10.1007/s00227-004-1542-0

Rojas de Astudillo, L. L. (2002). Chemical investigations on oysters and green mussels from Trinidad and Venezuela. PhD. Thesis. The University of the West Indies. Faculty of Science and Agriculture. Department of Chemistry.

Singh, J. G. (1988). A study of heavy metals and hydrocarbons in fish, crabs and mussels found in Trinidad. PhD. Thesis. The University of the West Indies. Faculty of Science and Agriculture.

Soliman, Z. I. (2006). A study of heavy metals pollution in some aquatic organisms in Suez Canal in Port- Said Harbour. Journal of Applied Sciences Research, 2(10), 657-663.

Sundberg, L. L. (1973). Interferences in nickel determinations by atomic absorption spectrometry. Analytical Chemistry, 45(8), 1460-1464. http://dx.doi.org/10.1021/ac60330a015

Tag El-Din, H. A., Habashy, M. M., \& Sultan, H. M. (2009). Residues of some heavy metals and hormones in fresh water prawns (Macrobracium Rosenbergii) and marine shrimp (Penaeus semisulcatus) with reference to the nutritive value. World Journal of Zoology, 4(3), 205-215.

Trinidad and Tobago. Ministry of Legal Affairs. 2007. Food and Drugs Act 8 of 1960 - Chapter 30.01. , 243. Regulation 62(18) (a) -Accepted levels of trace metals, pesticides and chemical for fish and fishery products.

Tu, N. P. C., Ha, N. N., Ikemoto, T., Tuyen, B. C.,Tanabe, S., \& Takeuchi, I. (2008). Regional variations in trace element concentrations in tissues of black tiger shrimp Penaeus monodon (Decapoda: Penaeidae) from South Vietnam. Marine Pollution Bulletin, 57(6-12), 858-866.

United Nations Environmental Programme. (2005). Regional awareness raising workshop on mercury pollution A global problem that needs to be addressed. Port of Spain, Trinidad and Tobago 18-21 January 2005.

United States Food and Drug Adminstration (US FDA). (1993). Guideline for toxic elements. Chapter 23: Environmental chemical contaminants and pesticides. In Seafood Network Information Center, Sea Grant Extension Program. - Sea Grant, Carlifornia. 2007, July 18.

Van den Broek, W. L. F. (1979). Seasonal levels of chlorinated hydrocarbons and heavy metals in fish and brown shrimps from the Medway estuary, Kent. Environmental Pollution, 19(1), 21-38. http://dx.doi.org/10.1016/0013-9327(79)90110-1

White, S. L., \& Rainbow, P. S. (1982). Regulation and accumulation of copper, zinc and cadmium by the shrimp Palaemon elegans. Marine Ecology - Progress Series, 8, 95-101.

Wu, X., \& Yang, Y. (2011). Heavy metal (Pb, Co, Cd, Cr, Cu, Fe, Mn and $\mathrm{Zn}$ ) concentrations in harvest-size white shrimp Litopenaeus vannamei tissues from aquaculture and wild source. Journal of Food Composition and Analysis, 24(1), 62-65. http://dx.doi.org/10.1016/j.jfca.2010.03.030

Yılmaz, A. B., \& Y1lmaz L. (2007). Influences of sex and seasons on levels of heavy metals in tissues of green tiger shrimp (Penaeus semisulcatus de Hann, 1844). Food Chemistry, 101(4), 1664-1669. http://dx.doi.org/10.1016/j.foodchem.2006.04.025 
Table 1. Maximum permitted levels of trace metals in foods (crustacean and sea foods) in Trinidad and Tobago for human consumption in relation to the metal findings in shrimp sampled in 2009

\begin{tabular}{|c|c|c|c|c|c|c|}
\hline Heavy metal contaminant & $\mathrm{Cd}^{1}$ & $\mathrm{Cr}^{1}$ & $\mathrm{Ni}^{1}$ & $\mathrm{Hg}^{2}$ & $\mathrm{Cu}^{3}$ & $\mathrm{Zn}^{3}$ \\
\hline $\begin{array}{c}\text { International and local } \\
\text { action level/ } \mu \mathrm{g} \mathrm{g}^{-1} \text { wet } \\
\text { wt. }\end{array}$ & 3 & 12 & 70 & 0.5 & 20 & 50 \\
\hline \hline Location (Sample Sites) & \multicolumn{4}{|c|}{ Mean \pm Standard Error for each metal in the shrimp samples/ $\mu \mathrm{g} \mathrm{g}^{-1}$ wet wt. } \\
\hline Orange Valley & $0.10 \pm 0.03$ & $0.18 \pm 0.04$ & $1.48 \pm 1.39$ & $0.08 \pm 0.00$ & $3.10 \pm 0.15$ & $10.02 \pm 0.20$ \\
\hline Port of Spain & $0.11 \pm 0.02$ & $0.11 \pm 0.06$ & $5.52 \pm 1.36$ & $0.06 \pm 0.01$ & $2.73 \pm 0.15$ & $10.05 \pm 0.20$ \\
\hline Otaheiti & $0.13 \pm 0.02$ & $0.13 \pm 0.04$ & $1.76 \pm 1.75$ & $0.07 \pm 0.01$ & $2.69 \pm 0.15$ & $10.43 \pm 0.20$ \\
\hline Claxton Bay & $0.11 \pm 0.03$ & $0.13 \pm 0.03$ & $<0.64^{*}$ & $0.06 \pm 0.01$ & $1.77 \pm 0.15$ & $8.99 \pm 0.20$ \\
\hline Tunapuna & $0.14 \pm 0.02$ & $0.10 \pm 0.10$ & $5.74 \pm 1.36$ & $0.07 \pm 0.00$ & $2.41 \pm 0.15$ & $10.16 \pm 0.20$ \\
\hline \hline
\end{tabular}

* Metal level in shrimp was $<$ LOQ ( $\mu \mathrm{g} \mathrm{g}^{-1}$ wet wt.).

Table 2. CRM mean recoveries (\%) \pm standard error

\begin{tabular}{|l|l|l|l|l|l|l|}
\hline CRM & $\mathrm{Cu}$ & $\mathrm{Zn}$ & $\mathrm{Cd}$ & $\mathrm{Cr}$ & $\mathrm{Ni}$ & $\mathrm{Hg}$ \\
\hline DOLT-4 & $107.29 \pm$ & $98.50 \pm$ & $95.53 \pm$ & $96.70 \pm$ & $117.33 \pm$ & $86.67 \pm$ \\
& 2.40 & 0.62 & 0.60 & 5.77 & 14.16 & 2.66 \\
\hline DORM-3 & $107.48 \pm$ & $98.28 \pm$ & $95.77 \pm$ & $91.83 \pm$ & $116.95 \pm$ & $98.60 \pm$ \\
& 2.63 & 1.44 & 2.06 & 5.00 & 12.63 & 12.16 \\
\hline DOLT-2 & $111.89 \pm$ & $102.65 \pm$ & & & & $92.27 \pm$ \\
& 3.77 & 2.06 & & & & 4.88 \\
\hline
\end{tabular}

Table 3. Significant effect of location by season interaction for $\mathrm{Cu}$ in shrimp and; location and seasonal differences of $\mathrm{Zn}$

\begin{tabular}{|c|c|c|c|c|}
\hline \multicolumn{3}{|c|}{$\begin{array}{l}\mathrm{Cu} \text { : location by season interaction showing } \\
\text { significant difference, } \mathrm{P} \text {-value }=\mathbf{0 . 0 3}\end{array}$} & \multicolumn{2}{|c|}{$\mathbf{Z n}$} \\
\hline Location & $\begin{array}{c}\text { Wet Season: } \\
\text { Mean } \pm \text { Standard } \\
\text { Error }(\mu \mathrm{g} / \mathrm{g}) \text { wet } \\
\text { wt. }\end{array}$ & $\begin{array}{c}\text { Dry Season: } \\
\text { Mean } \pm \text { Standard } \\
\text { Error }(\mu \mathrm{g} / \mathrm{g}) \text { wet } \\
\text { wt. }\end{array}$ & $\begin{array}{l}\text { Location differences of Zn: } \\
\text { Mean } \pm \text { Standard Error } \\
(\mu \mathrm{g} / \mathrm{g}) \text { wet wt.; } \\
(\mathrm{P}-\mathrm{value}=0.00)\end{array}$ & $\begin{array}{c}\text { Seasonal differences of } \mathrm{Zn} \\
\text { Mean } \pm \text { Standard Error } \\
(\mu \mathrm{g} / \mathrm{g}) \text { wet wt.; } \\
(\mathrm{P}-\text { value }=0.02)\end{array}$ \\
\hline $\begin{array}{l}\text { Orange } \\
\text { Valley }\end{array}$ & $2.38 \pm 0.21$ & $3.82 \pm 0.21$ & $10.02 \pm 0.20$ & Wet: $9.71 \pm 0.13$ \\
\hline $\begin{array}{l}\text { Port of } \\
\text { Spain }\end{array}$ & $2.19 \pm 0.21$ & $3.28 \pm 0.21$ & $10.05 \pm 0.20$ & Dry: $10.15 \pm 0.13$ \\
\hline Otaheiti & $1.99 \pm 0.21$ & $3.39 \pm 0.21$ & $10.43 \pm 0.20$ & \\
\hline $\begin{array}{c}\text { Claxton } \\
\text { Bay }\end{array}$ & $1.66 \pm 0.21$ & $1.87 \pm 0.21$ & $8.99 \pm 0.20$ & \\
\hline Tunapuna & $1.95 \pm 0.21$ & $2.86 \pm 0.21$ & $10.61 \pm 0.20$ & \\
\hline
\end{tabular}

